\title{
MODEL OF MICROCLIMATIC INFLUENCE ON FLUCTUATION OF HERPETOFAUNA DIVERSITY IN CAMPUS AREA
}

\author{
Tony F. Qurniawan \\ Faculty of Biology \\ Universitas Gadjah Mada \\ Email: tony_qurniawan@yahoo.com
}

\begin{abstract}
ABSTRAK
Studi tentang hubungan akibat perubahan iklim mikro terhadap fluktuasi keanekaragaman herpetofauna di area kampus dilakukan selama enam tahun terakhir. Pemantauan keragaman herpetofauna dilakukan 2007-2012 menggunakan Visual Encounter Survey. Analisis untuk merancang model pengaruh iklim mikro terhadap fluktuasi keanekaragaman herpetofauna dilakukan dengan menggunakan program Smart PLS . Hasil penelitian menunjukkan 8 spesies amfibi dua puluh empat (24) jenis reptil yang diidentifikasi selama enam tahun terakhir 2007-2012. Berhasil didata dan dicatat persebaran baru untuk jenis Lepidodactylus cf lugubris (Geckonidae). Hasil penelitian juga menunjukkan bahwa fluktuasi keanekaragaman herpetofauna di kawasan kampus dipengaruhi oleh iklim mikro. Model pengaruh iklim mikro terhadap fluktuasi keanekaragaman herpetofauna menunjukkan bahwa kelembaban menjadi faktor utama yang mempengaruhi fluktuasi keanekaragaman herpetofauna di daerah kampus dengan prediksi - relevansi ( Q2 ) nilainya $99.817 \%$.
\end{abstract}

Kata Kunci: Monitoring; Reptil; Amphibia; Pemodelan path; PLS

\begin{abstract}
The study on correlation of microclimates changes on fluctuations of herpetofauna diversity in campus area was done for the last six years. Monitoring herpetofauna diversity was conducted from 2007 to 2012 using Visual Encounter Survey. The analysis for designing a model on the influence of microclimates on fluctuations of herpetofauna diversity performed by using smart PLS program. The result showed eight (8) species of amphibians and twenty four (24) species of reptiles were identified within the last six-year visits (2007-2012). New country records of Lepidodactylus of lugubris (Geckonidae) species were documented. The results also showed that fluctuations of herpetofauna diversity in campus area was influenced by microclimates elements. The model of microclimatic influence on fluctuations of herpetofauna diversity showed that the humadity becomes a major factor influencing on fluctuations of herpetofauna diversity in campus area with the predictive-relevance (Q2) value is $99,817 \%$.
\end{abstract}

Keywords: Monitoring; Reptile; Amphibian; Path modeling; Partial Least Squares 


\section{INTRODUCTION}

Climate is the average weather conditions in an area for a long time. Climate is a substance that plays an important role in life. Climate can be classified into microclimate and macroclimate. Macroclimate is the climate of a larger area such as a region or a country and Microclimate is the variations in localised climate around a building or small area. Microclimate is composed by several matter and each matter has a different effect on different regions. Rainfall, humidity and temperature are the dominant matters of the microclimate in tropical countries such as Indonesia. Indonesia's microclimates is very varied between one region to another. The change dry season in to the rainy season can be clearly distinguishable. Effect of microclimate change is a interesting topic discussed by herpetolog because the climate can affect development, reproduction, behavior, abundance, and survival of herpetofauna.

Herpetofauna was a group of animals which composed of amphibians and reptiles. Herpetofauna was exothermic animals in which all aspects of their lives strongly influenced by the environment. This makes herpetofauna can be used as bio-indicators of environmental (Duellman \& Trueb, 1994). Until now the herpetofauna in the world's population is declining and some extinct. Hence this study was undertaken to investigate the effects of microclimate (rainfall, humidity and temperature) to changes in the diversity and abundance of the herpetofauna at the University of Gadjah Mada campus area for the last six years. Gadjah Mada University (UGM) has a large area (357 ha) with a variety of habitats, such as artificial forest, permanent ponds, gardens and open fields. This habitats was a potential for the existence of the herpetofauna in the campus area.

\section{Methods}

The method of Visual Encounter Surveys had been conducted with the survey frequency of six times in each year (2007-2012).
The surveys was carried out in seven campus main areas, specifically the river area of Mataram, eastern areas of Kaliurang street, the building center area, the arboretum of UGM, the artificial garden of UGM, the forest of UGM, and the artificial valley of UGM. Specimens were euthanized using approved methods as recommended by the LIPI and Indonesian Herpetologists. All specimens were preserved in 10\% formalin and stored in $70 \%$ ethanol. The specimens are deposited in the collections of the UGM Laboratory Animal Taxonomy. Data survey results will be presented in the form of tables displaying species for each year. Identification of the type and naming refers to some literature, namely Rooij (1915; 1917), Kampen (1923), Iskandar and Colijn (2001), Mauesfeld et.al (2000), Carranza and Arnold (2005), Frost (2011), Vogel and David (2012), Qurniawan et.al (2012) and Uetz and Hosek (2013).

The diversity data was analyzed using the Shannon-Wiener index diversity (Magurran 1988). The index diversity calculated following this formula:

$$
H^{\prime}=-\sum P i \operatorname{LnPi}
$$

Explanation:

$\mathrm{H}^{\prime}=$ Shannon-Wiener index diversity

$\mathrm{Pi}=$ Proportion of species to- $\mathrm{i}$

The analysis of evenness following this formula:

$$
E=\frac{H^{\prime}}{\operatorname{Ln} S}
$$

Explanation:

$\mathrm{E}=$ Evenness index

$\mathrm{H}^{\prime}=$ Shannon-Wiener index diversity

$S=$ The number of species found

Smart PLS program used to test the accuracy of path model design to know the interaction effect of microclimates (rainfall, humidity and temperature) on fluctuation herpetofauna diversity and evenness in campus area was done for the last six years (20072012). The stages were used in smart PLS for 
make microclimatic modelling consist if six step: (1) constructing a structural model (inner model), (2) evaluating significant outer weight value, (3) constructing a measurement model (outer model), (4) evaluation Goodness of Fit, (5) estimation predictive-relevance $\left(\mathrm{Q}^{2}\right)$, (6) Bootstraping and t-test with an alpha of $5 \%$.

\section{RESULTS AND DISCUSSION \\ Monitoring Herpetofauna Diversity}

Our surveys of the herpetofauna at Universitas Gadjah Mada revealed a total of
32 species of anurans, lizards, and snakes (Table 1). Endemic freshwater snakes of Xenochrophis melanzostus and a new record for Lepidodactylus lugubris (Geckonidae) were not expected to be present. Xenochrophis melanzostus is endemic to Java and Bali and was recently reported to be found in Bali (Vogel and David 2012; Kusuma et al. 2010). Amphibians were collected in a greater number than the number of reptiles, although the diversity of reptiles was higher.

Table 1

The list of Herpetofauna Diversity of Gadjah Mada University campus area over the time herpetofauna. Endemic species are marked with ${ }^{* *}$ and threatened species listed in CITES and IUCN are marked with *.

\begin{tabular}{|c|c|c|c|c|c|c|c|}
\hline No & TAXA & 2007 & 2008 & 2009 & 2010 & 2011 & 2012 \\
\hline & Amphibia & & & & & & \\
\hline & Anura & & & & & & \\
\hline & Bufonidae & & & & & & \\
\hline \multirow[t]{2}{*}{1} & Duttaphrynus melanostictus (Schneider, 1799) & + & + & + & + & + & + \\
\hline & Micrhohylidae & & & & & & \\
\hline 2 & Microhyla palmipes Boulenger, 1897 & - & + & + & - & - & - \\
\hline \multirow[t]{2}{*}{3} & Kaloula baleata (Müller, 1836) & + & + & + & + & + & - \\
\hline & Dicroglossidae & & & & & & \\
\hline 4 & Fejervarya limnocharis (Gravenhorst, 1829) & + & + & + & - & - & + \\
\hline 5 & Occidozyga sumatranus (Peters, 1877) & + & - & - & - & - & - \\
\hline \multirow[t]{2}{*}{6} & Occidozyga lima (Gravenhorst, 1929) & - & + & - & - & - & - \\
\hline & Rhacophoridae & & & & & & \\
\hline \multirow[t]{2}{*}{7} & Polypedates leucomystax (Gravenhorst, 1829) & + & + & + & + & + & + \\
\hline & Ranidae & & & & & & \\
\hline \multirow[t]{4}{*}{8} & Hylarana chalconota (Schlegel,1837) & + & + & + & - & + & - \\
\hline & Reptilia & & & & & & \\
\hline & Lacertilia & & & & & & \\
\hline & Gekkonidae & & & & & & \\
\hline 9 & Lepidodactylus of lugubris & - & - & - & - & + & - \\
\hline 10 & Cyrtodactylus marmoratus (Gray, 1831) & - & + & - & - & - & - \\
\hline 11 & Gehyra mutilata (Wiegmann, 1834) & - & - & - & + & + & + \\
\hline 12 & Hemydactylus frenatus Schlegel, 1836 & + & + & + & + & + & + \\
\hline 13 & Hemyphyllodactylus typus Bleeker, 1860 & - & - & - & - & + & - \\
\hline 14 & Hemydactylus platyurus (Schneider, 1792) & - & - & - & + & + & - \\
\hline \multirow[t]{2}{*}{15} & Gekko gecko (Linnaeus, 1758) & + & + & + & + & + & + \\
\hline & Agamidae & & & & & & \\
\hline 16 & Draco volans Linnaeus, 1758 & - & - & + & - & + & + \\
\hline 17 & Bronchocela cristatella (Kuhl, 1820) & + & + & + & + & + & + \\
\hline \multirow[t]{2}{*}{18} & Bronchocela jubata (Dumeril \& Bibron, 1837) & + & + & + & + & + & + \\
\hline & Scincidae & & & & & & \\
\hline \multirow[t]{3}{*}{19} & Eutropis multifasciata (Kuhl, 1820) & + & + & - & - & + & + \\
\hline & Ophidia & & & & & & \\
\hline & Typhlopidae & & & & & & \\
\hline
\end{tabular}




\begin{tabular}{|c|c|c|c|c|c|c|c|}
\hline No & TAXA & 2007 & 2008 & 2009 & 2010 & 2011 & 2012 \\
\hline 20 & $\begin{array}{l}\text { Ramphotyphlops braminus (Daudin, 1803) } \\
\text { Phythonidae }\end{array}$ & - & - & + & + & + & + \\
\hline 21 & $\begin{array}{l}\text { Phython reticulatus (Schneider, 1801) } \\
\text { Colubridae }\end{array}$ & - & - & - & - & - & + \\
\hline 22 & Ahaetulla prasina (Boie, 1827) & + & + & + & - & + & + \\
\hline 23 & Dendrelaphis pictus (Gmelin, 1789) & - & - & - & + & - & - \\
\hline 24 & Coelognathus flavolineatus (Schlegel, 1837) & - & + & + & - & - & + \\
\hline 25 & Coelognathus radiatus (Boie, 1827) & - & - & - & - & + & - \\
\hline 26 & Lycodon capucinus Boie, 1827 & - & - & + & - & + & + \\
\hline 27 & Enhydris enhydris (Schneider, 1799) & + & - & - & - & - & - \\
\hline 28 & Rhadophis subminiatus (Schlegel, 1837) & - & + & + & - & - & - \\
\hline 29 & Xenochrophis trianguligerus (Boie, 1827) & - & + & + & + & + & + \\
\hline 30 & $\begin{array}{l}\text { Xenochrophis melanzostus (Schneider, 1799) } \\
\text { Elapidae }\end{array}$ & - & - & + & - & - & - \\
\hline 31 & Bungarus fasciatus (Schneider, 1801) & - & + & - & - & - & - \\
\hline 32 & Naja sputatrix (Boie, 1827$)$ & + & - & - & - & - & - \\
\hline & TOTAL & 14 & 18 & 18 & 12 & 19 & 16 \\
\hline
\end{tabular}

Based on Table 1, it can be seen that from 2007-2012, 32 species of reptiles and amphibians are found which consist of 8 species of anurans, 11 species of lizard, and 13 species of snake. Reptile species are more common than amphibian species because the area around the campus is dominated by grassland and arboretum. They are an ideal type of habitat for reptiles. The number of amphibians are smaller because there is less site for breeding wich secure from predators for amphibians and thus, with minimum water, only some frogs or toads which can live here.

There are some species found in all year survey such as Duttaphrynus melanostictus, Polypedates leucomystax, Hemidactylus frenatus, Gekko gecko, Bronchocela jubata, and Bronchocela cristatella (Figure 1b-e). They are cosmopolitan species that can live near human habitation and human activities. The other species are not found each year from 20072012.

Based on the result of the total species in each year, the highest number of species is in 2011 which is 19 species and the lowest number of species is in 2010 which is 12 species. The lowest number of herpetofauna in 2010 may be caused by the eruption of Mount
Merapi in 2010. The dust of Merapi eruption has changed the microclimatic of campus environment. It made some species can no longer survive in their habitat. They either moved from their habitat or died.

The interesting thing found from the results is the first record of Lepidodactylus of lugubris (Geckonidae) specimen from Java (Figure 1a). According to Uetz and Hosek (2013), there was no record of those species in Java Island. Its distribution ranges only in Borneo, Lombok, Sulawesi, Halmahera, Ambon, Kei Islands and Komodo. This first publication contains records of Lepidodactylus of lugubris distribution in Java Island and needs to be studied again.

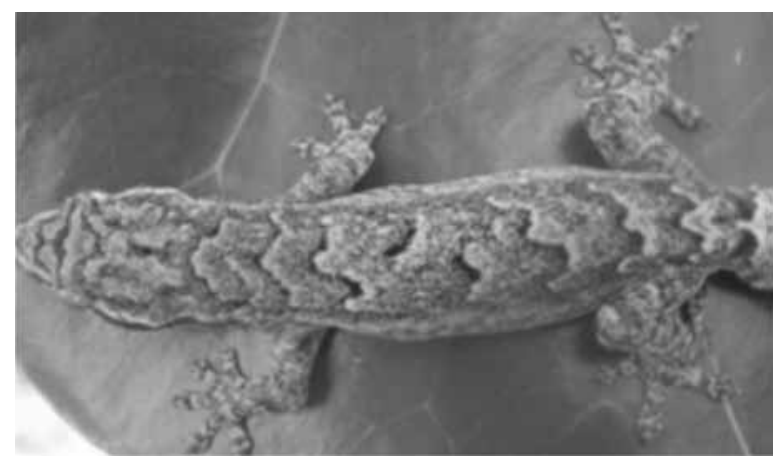

a 


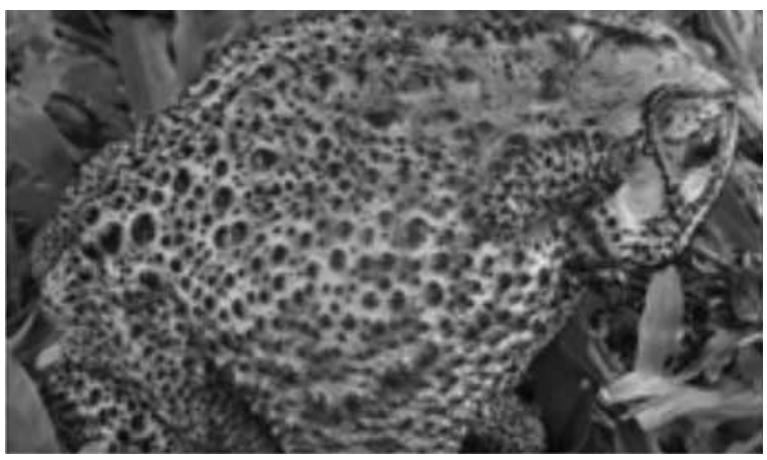

b

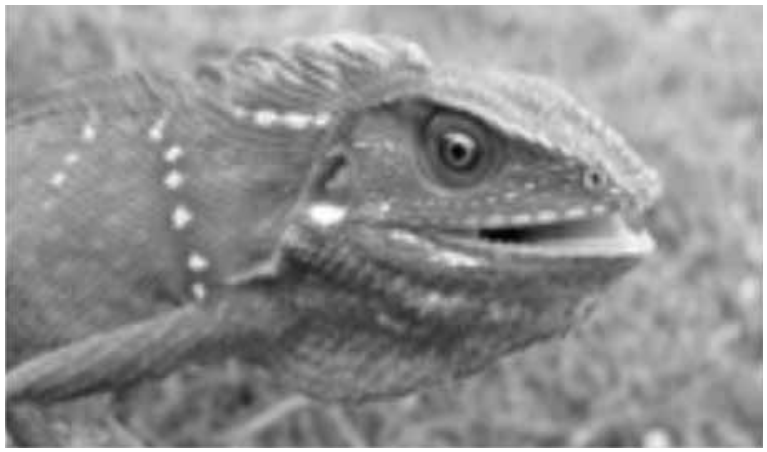

C

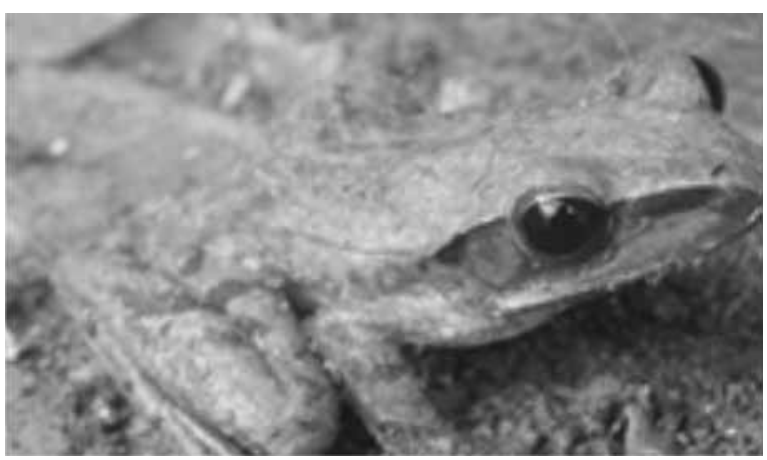

d

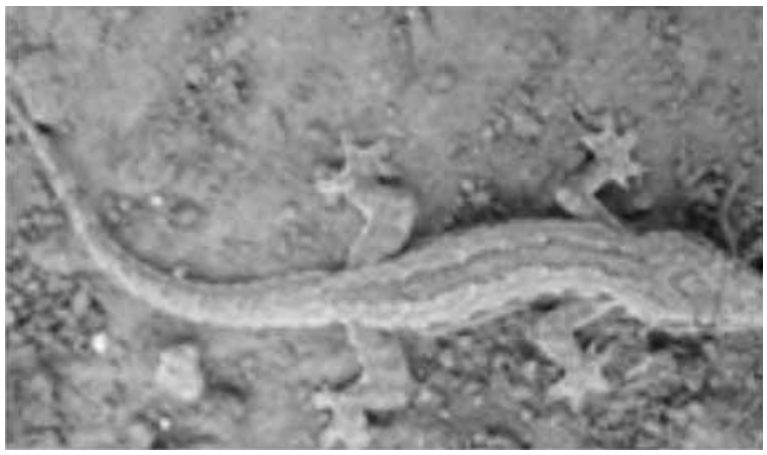

$\mathrm{e}$

Figure 1

Lepidodactylus cf lugubris (a), Duttaphrynus melanostictus (b), Bronchocela jubata (c), Polypedates leucomystax (d), Hemidactylus frenatus (e), (1 bar = $5 \mathrm{~mm})$

\section{Analysis on Modelling of Microclimatic Effect}

A model can be defined as a representation of a system used to learn system of reality, its components and the path connections between the components. Modeling using PLS has 2 model tests, which are evaluations of inner model and outer model. Inner model is a structural model which connects latent variables. Outer model is a measurement model which connects indicators with their latent variables. Outer model test is to see which indicators are significant in forming the latent variables. Outer model test is to see the significant influence on latent variables. Based on outer model test, it's discovered that temperature, $\mathrm{pH}$, humidity and rainfall indicators formed their own latent variables. Inner model test was performed using $t$ test on each path (this study showed that there was a significant path connection between each latent variable).

From the $t$ test of each path it was discover that all significant path had connections ( $p$-value $<0,05$ ) and influenced other variables (as shown in Figure 2). Humidity variable had significant connection with rainfall variable. Rainfall variable had significant connection with temperature variable. Temperature variable had a significant connection with evenness variable. Evenness variable had a significant connection with diversity. To discover the influence of the connections between the variables above the Goodness of Fit should be tested.

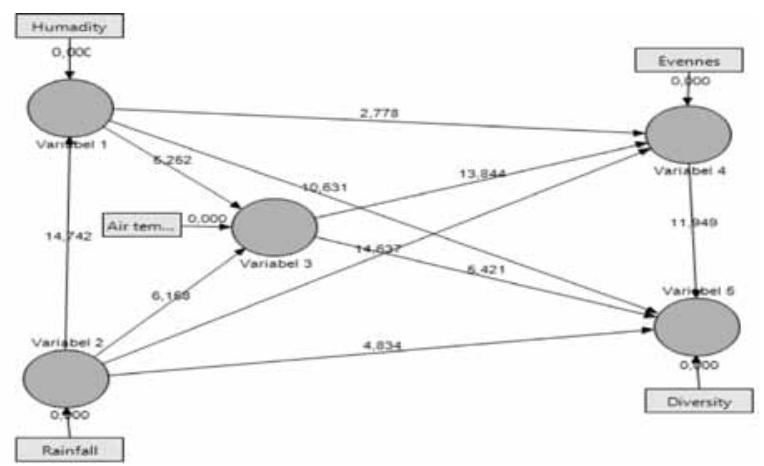

Figure 2

the result of $t$ test on inner model path connection. (significant on a $5 \%$, if the result t-statistic $>1.96$ ) 
The result of Goodness of Fit test on inner model showed R2 of each variable in this study as follows: (1) Humidity Variable has R2 of 0.449 . Meaning $44.9 \%$ humidity was influenced by rainfall; (2) Temperature Variable has $\mathrm{R} 2$ of 0.189 . Meaning $18.9 \%$ temperature was influenced by rainfall and humidity; (3) Evenness Variable has R2 of 0.938. Meaning $93.8 \%$ evenness was influenced by rainfall, temperature and humidity; (4) Diversity Variable was R2 of 0.934 . Meaning $93.4 \%$ diversity was influenced by rainfall, temperature, humidity and evenness.

The calculation showed that predictiverelevance Q2 value is $99.817 \%$ and more than $80 \%$, so model was fit for use and had very relevant predictive value. Information contained in $99.817 \%$ data is explained in the final PLS model in Figure 2. While the remaining $0.183 \%$ was explained by other variables not contained in the model. Inner model test was performed using $t$ test on each direct influence track between variables partially. The complete analysis result was each latent variable had two types of connections which are direct connection and indirect connection (as shown in Figure 3).

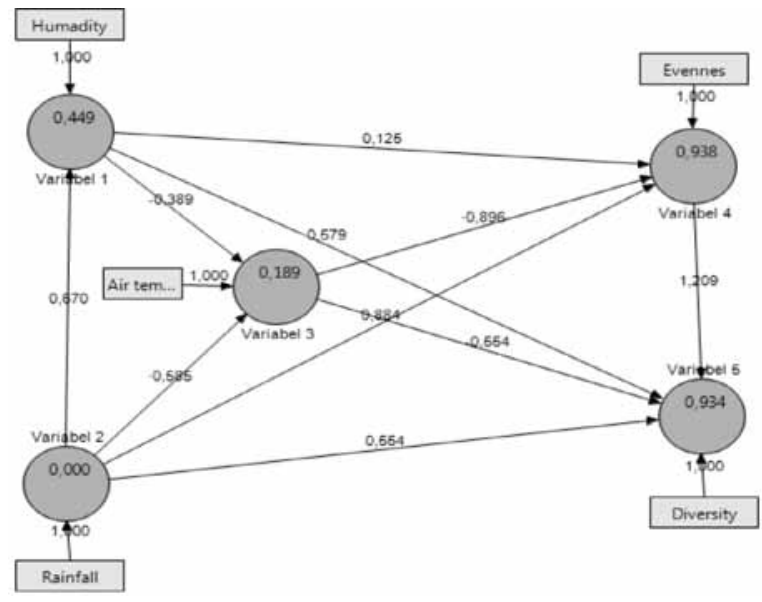

Figure 3

The Result of Goodness of Fit Test on Inner Model

Based on the analysis result the variables which have connections with direct influences included: firstly, Direct influence of rainfall variable influenced humidity, temperature and evenness with the coefficients of, respectively, 0.870 (if rainfall increased, humidity would be higher), -0.586 (if rainfall increased, then temperature would be decrease), and 0.884 (high rainfall would increase diversity). Secondly, Direct influence of humidity variable influenced diversity with the coefficients of 0.579 (the higher the humidity, the higher the diversity). Thirdly, Direct influence of temperature variable influenced evenness with the coefficients of -0.896 . It is mean that the higher the temperature, the lower the evenness. Fourthly, Direct influence of evenness variable influenced diversity with the coefficients of 1.209. Meaning the higher the evenness the higher the diversity.

In addition to direct influence, there were significant indirect influences: Firstly, Indirect influence of rainfall variable on diversity. The coefficient of indirect influence was 0.554 . Meaning the increase of humidity and evenness would increase diversity if the rainfall also increased. Secondly, Indirect influence of temperature variable on diversity. The coefficient of indirect influence was -0.554 . Meaning the increase of humidity and evenness would increase diversity if the temperature dropped. Thirdly, Indirect influence of humidity variable on temperature. The coefficient of indirect influence was -0.369 , meaning the increase of rainfall would lower temperature if humidity also increased. Fourthly, Indirect influence of humidity on evenness. The coefficient of indirect influence was 0.125 , meaning the increase of rainfall and decrease of temperature would lower evenness if humidity also increased.

The PLS model made had predictiverelevance Q2 value of $99.817 \%$, so the model was fit for use and had very relevant predictive value. It meant that $99.817 \%$ modeling had represented current variables and the remaining $0.183 \%$ was explained by other variables not included in this model. 


\section{CONCLUSIONS}

Based on the survey results, we know that the diversity of reptiles and amphibians in Gadjah Mada University campus area for the last six years (2007-2012) consist of 32 species. Based on the result of analysis PLS modeling, it could be concluded that the variables which had direct influences influenced herpetofauna diversity in the campus area for six years were humidity and evenness while rainfall and temperature variables significantly influenced herpetofauna diversity indirectly.

\section{ACKNOWLEDGMENTS}

I would like to thank for to thanks to Endang Arisoesilaningsih from UNIBRAW and Budiman Panji from UNWAMA for all kindness and knowledge sharing about Smart PLS Path Modeling Analysis.

\section{BIBLOGRAPHY}

Carranza S and E.N. Arnold. 2005. Systematics, biogeography, and evolution of Hemidactylus geckos (Reptilia: Gekkonidae) elucidated using mitochondrialDNA sequences. Molecular Phylogenetics and Evolution $38: 531-545$.

Duellman, W.E. \& Trueb, L. 1994. Biology of Amphibians. Johns Hopkins Univ Press. London.

Frost, Darrel R. 2013. Amphibian Species of the World: an Online Reference. Version 5.6. Electronic Database accessible at http://research.amnh.org/vz/ herpetology/amphibia. Captured on 9 January 2013.

Iskandar, D. T. and E. Colijn. 2001. Preliminary Checklist of Southeast Asian and New Guinean Reptiles Part I: Serpentes. The Gibbon Foundation. Jakarta.
Kampen, van P.N. 1923. The amphibian of the Indo-Australia Archipelago. E.J. Brill Ltd. Leiden.

Kusuma, K.I., Eprilurahman R. and Vogel, G. (2010) First record of Xenochrophis melanzostus (Gravenhorst, 1807) on Bali Island, Indonesia. Hamadryad, 35(1), 113-115.

Magurran A. E. (1988) Ecologycal diversity and its measurement. London, Croom Helm.

Mausfeld. Patrick, Miguel Vences, Andreas Schmitz, and Michael Veith. 2000. First Data on the Molecular Phylogeography of Scincid Lizards of the Genus Mabuya. Molecular Phylogenetics and Evolution 17(1) :1114.

Qurniawan T.F., Tuty Arisuryanti and Niken Satuti Nur Handayani. 2012. Karyiotype Analysis of Trawang Snake (Coelognathus radiatus (Boie 1827)). Jurnal Biologi Indonesia 8 (2): 247-254.

Rooij, N.De. 1915. The Reptiles of the IndoAustralian Archipelago I. Lacertilia, Chelonia, Emydosauria. EJ Brill. Leiden, The Netherlands.

Rooij, N.De. 1917. The Reptiles of the IndoAustralian Archipelago II. Ophidia. EJ Brill. Leiden, The Netherlands.

Uetz, P. and Jirí Hošek. 2013. The Reptile Database, Electronic Database accessible at http://www.reptiledatabase.org, Captured on 1 Apr 2013.

Vogel, G \& P.David .2012. A revision of the species group of Xenochrophis piscator (Schneider, 1799) (Squamata: Natricidae) Zootaxa 3473: 1-60. 